\title{
"STOP the PUFF! Tayo'y mag bagong BAGA, SIGARILYO aY ITIGIL": A Pilot Community-based Tobacco Intervention Project in an Urban Settlement
}

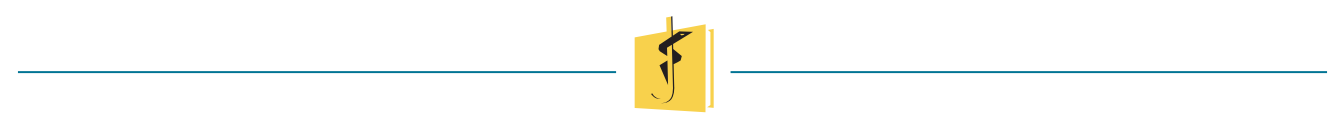

Irene Salve D. Joson-Vergara, MD, Julie T. Li-Yu, MD

\begin{abstract}
The success rate for smoking cessation in the country remain low despite the intensified efforts of the governmentto curb smoking. There is a need to support tobacco control policies with clinical interventions for smoking cessation. However, cessation experts in the country are few and healthcare workers with training on tobacco interventions are limited. The project aimed to address the clinical aspect of tobacco control by establishing tobacco cessation services in the community. This was done by providing brief tobacco intervention training among health workers and community leaders, thus allowing this intervention to be integrated in the existing programs of the community health center. This also led to the creation of possible referral mechanisms to cessation support providers. This was complemented with health education activities that promote smokefree behavior.
\end{abstract}

Keywords: tobacco; cigarette smoking; tobacco dependence; smoking cessation; brief advice; brief tobacco intervention

Irene Salve D. Joson-Vergara

ijvergara@ust.edu.ph

Department of Medicine, Faculty of Medicine and Surgery, University of Santo Tomas, Manila, Philippines

\section{INTRODUCTION}

Tobacco use continue to be one of the leading cause of death and disability worldwide. Around 8 million deaths worldwide each year are tobacco related, 7 million of which are attributed to direct tobacco use while around 1.2 million are due to exposure to secondhand smoke. There are around 1.1 billion smokers worldwide and $80 \%$ of these live in lowand middle-income countries [1]. The Philippines is one of the countries in the Western Pacific region with the highest prevalence of tobacco use [2] and seven out of the 10 leading cause of mortality in the country is tobacco related. [3] The Philippine government has intensified its efforts to curb smoking, focusing mainly on policies that target the wider determinants of health such as smoking bans, graphic health warnings and $\sin$ tax law. These efforts have resulted to a significant decrease in the prevalence of smoking from 17.3 million in 2009 to 15.9 million in 2015 . Also, the number of smokers who are interested in quitting increased by $16.3 \%$ from 2009 to 2015 . However, those interested in quitting that were seen by a health care provider did not increase significantly and only around half made a quit attempt. More importantly, the quit success rate did not increase. [4] This demonstrates a wide disparity between the number of smokers who want to quit and the number who are able to quit successfully. This gap may be addressed by strengthening health 
care interventions especially among smokers that are heavily dependent on nicotine. There may be a need to complement national policies with programs that target the specific needs of smokers.

Brief Tobacco Intervention (BTI), also known as brief advice, is a strategy that is proven to be effective, practical and doable in the community setting. [5] Unfortunately, cessation experts in the country are few and healthcare workers with training on tobacco interventions are limited.

The primary objective of the project was to establish smoking cessation intervention in the community by empowering health workers and community volunteers on giving BTI and to improve access to cessation support by establishing a referral mechanism to smoking cessation services. The project also aimed to promote smoking cessation in the community through health education activities that promote smoke-free behavior and encourage smoking cessation among current smokers.

\section{Review of Related Literature}

Studies have shown that the outcome of quit attempt is related to various individual, socio-cultural and environmental factors. [6-13] Some factors were consistently shown to be related to quit success but there are certain factors that differ in every population. Studies done among smokers in South Africa, USA and South Korea showed that higher educational level is related to quit success. [6-8] However, in a similar study done in Brazil, this was correlated with failure. [9] Being married was associated with quit success in the studies done in USA and in South Korea [7,8] however, this was not seen in the study done in South Africa. [6-10] It can be surmised therefore, that cultural, social and behavioral aspects of smoking that affect quit outcomes may be unique in each population or community (Table 1, Appendix A).

DiGiacomo et al [14] recommends a multifaceted approach in smoking cessation, taking into consideration the individual and socio-cultural factors that are unique to each community. These factors are usually not targeted by national policies that focus on the wider determinants of health. Community-based interventions, on the other hand, may better address these factors. There is also evidence that communitybased interventions and those that are tailored to specific indigenous groups have greater retention and quit success rates compared to center-based interventions. [14-20] These suggest that establishing a community-based smoking cessation intervention is effective and feasible (Table 2, Appendix A).

\section{METHODOLOGY}

The project was done in three phases as described in Table 3. A health needs assessment and situational analysis were done in the first phase. This involved an appraisal of the attributes of the community and an analysis of the specific needs of the community pertaining to tobacco control. This was done primarily through review of secondary data, focus group discussions (FGDs) and informal interviews. The primary goals of the FGDs were to understand the general views of the community on tobacco, determine the level of awareness on its effects and identify misconceptions on tobacco use and smoking cessation. The findings were used to modify the design of the training and health education modules to better fit the needs and attributes of the community.

Phase 2 of the project involved the conduct of BTI training for health workers and volunteers in Munting llaw health center. The training was done in two separate sessions to align with the health workers' schedule and minimize interruption in the delivery of services of the health center. The target number of participants was 30 , in accordance with the $\mathrm{WHO}$ recommendations. [5] The general objective of the seminar and workshop is to capacitate the participants on the method of conducting brief tobacco intervention. The module used was adopted from the BTI module of the Department of Health [21] and modified based on the result of the situational analysis. It consisted of 5 modules namely: 1. Building the Momentum; 2. Brief tobacco Intervention Essentials; 3. Not ready to quit; 4. Ready to quit; and 5. Staying quit or relapse. The description, contents, methodology and resources of the modules are summarized in Table 5 (Appendix B). Gaps in knowledge, concerns and misconceptions identified during the FGDs were given emphasis during the training. Possible referral mechanisms to smoking cessation services were discussed at the end of the session.

Phase 3 of the program involved health promotion activities such as information campaign on the dangers of smoking and promotion of smoking cessation services. This was done in the form of a lay fora. 
Table 3. Project Design

\begin{tabular}{|c|c|c|c|c|}
\hline PHASES & STAKEHOLDERS & RESOURCES & OUTCOME & MONITORING \\
\hline $\begin{array}{l}\text { 1. Health Needs } \\
\text { Assessment } \\
\text { Interviews/ } \\
\text { Focus Group } \\
\text { Discussions }\end{array}$ & $\begin{array}{l}\text { Barangay Health } \\
\text { Officer } \\
\text { Barangay Health } \\
\text { Workers/Volunteers } \\
\text { Community Leaders }\end{array}$ & Questionnaires & $\begin{array}{l}\text { Inventory of available } \\
\text { cessation services and } \\
\text { manpower } \\
\text { Qualitative data on } \\
\text { the perception of the } \\
\text { community regarding } \\
\text { smoking and smoking } \\
\text { cessation }\end{array}$ & $\begin{array}{l}\text { Accomplished needs } \\
\text { assessment }\end{array}$ \\
\hline $\begin{array}{l}\text { 2. Training of } \\
\text { HWs and } \\
\text { Volunteers on } \\
\text { Brief Cessation } \\
\text { Advice }\end{array}$ & $\begin{array}{l}\text { Barangay Health } \\
\text { Officer } \\
\text { Barangay } \\
\text { HWs/Volunteers }\end{array}$ & $\begin{array}{l}\text { Cessation Expert } \\
\text { Training Module } \\
\text { Venue } \\
\text { Training Materials }\end{array}$ & $\begin{array}{l}100 \% \text { attendance by all } \\
\text { HWs } \\
\text { All HW's are } \\
\text { knowledgeable on brief } \\
\text { cessation advice }\end{array}$ & $\begin{array}{l}\text { Attendance sheet } \\
\text { Post-test }\end{array}$ \\
\hline $\begin{array}{l}\text { 3. Creation of a } \\
\text { referral } \\
\text { pathway }\end{array}$ & $\begin{array}{l}\text { Barangay Health } \\
\text { Officer } \\
\text { Smoking cessation } \\
\text { clinics }\end{array}$ & $\begin{array}{l}\text { DOH data } \\
\text { Inventory of available } \\
\text { cessation services } \\
\text { and providers }\end{array}$ & Referral pathway & $\begin{array}{l}\text { No. of patients } \\
\text { referred to smoking } \\
\text { cessation clinics/ } \\
\text { quitline }\end{array}$ \\
\hline $\begin{array}{l}\text { 4. Health } \\
\text { Information } \\
\text { Campaign }\end{array}$ & $\begin{array}{l}\text { Barangay/Rural Health } \\
\text { Officer } \\
\text { Community Leaders } \\
\text { Community Members }\end{array}$ & $\begin{array}{l}\text { Health Education } \\
\text { Materials } \\
\text { (flyers/posters) }\end{array}$ & $\begin{array}{l}\text { Game show } \\
\text { Lay fora }\end{array}$ & $\begin{array}{l}\text { Attendance sheet } \\
\text { Post-test }\end{array}$ \\
\hline
\end{tabular}

Table 4. Actual Schedule of Activities

\begin{tabular}{|c|c|c|}
\hline ACTIVITY & DATE/TIME & VENUE AND PARTICIPANTS \\
\hline $\begin{array}{l}\text { 1. Focused Group Discussion } \\
\text { with BHW's }\end{array}$ & November 11 (Monday) 12pm to 1pm & $\begin{array}{l}\text { Venue: Kasiglahan Village Health } \\
\text { Center }\end{array}$ \\
\hline 2. Interview with MHO & November 20, 2019 & Venue: RHU \\
\hline \multirow[t]{2}{*}{$\begin{array}{l}\text { 3. Brief Tobacco Intervention } \\
\text { Seminar }\end{array}$} & $\begin{array}{l}\text { Part } 1 \text { (Module } 1 \text { and 2): November } 21 \\
\text { (Thursday) } 1 \mathrm{pm} \text { to } 4 \mathrm{pm}\end{array}$ & $\begin{array}{l}\text { Venue: Munting llaw } \\
\text { Participants: BHW's }\end{array}$ \\
\hline & $\begin{array}{l}\text { Part } 2 \text { (Module 3,4 and 5): November } \\
28 \text { (Thursday) } 1 \mathrm{pm} \text { to } 4 \mathrm{pm}\end{array}$ & \\
\hline 4. Health Promotion Activity & December 7 (Saturday), 8am onwards & $\begin{array}{l}\text { Venue: Phase } 1 \mathrm{~K} \text { Covered Court } \\
\text { Participants: community leaders and } \\
\text { members }\end{array}$ \\
\hline $\begin{array}{l}\text { 5. Focused Group Discussion } \\
\text { with community members }\end{array}$ & $\begin{array}{l}\text { Every Monday and Friday } \\
\text { FGD1: Smokers } \\
\text { FGD2: Former Smokers } \\
\text { FGD3: Spouse/Children/Relative of } \\
\text { smokers } \\
\text { FGD4: non-smokers exposed to SHS }\end{array}$ & Participants ( 3 to 5 per session) \\
\hline Data Gathering & October to December, 2019 & \\
\hline
\end{tabular}

The actual schedule of the conduct of activities is presented in Table 4.

\section{OBSERVATIONS AND RESULTS}

\section{A. Health Needs Assessment}

\section{Health Profile of the Community}

The project was implemented in Phase 1-K Kasiglahan Village, Barangay San Jose, Rodriguez
Rizal where a memorandum of agreement exists between Barangay San Jose and the University of Santo Tomas, Master in Public Health (International) program. Kasiglahan Village is situated in Barangay San Jose which is one of the eleven barangays in Rodriguez Rizal. Although originally an agricultural land, the area has undergone massive development over the recent years and is now considered as an urban area. It is the $6^{\text {th }}$ most populated barangay in Rodriguez with a population of 124,868 in 2015. 
This population has grown quite rapidly over the past few decades largely due to the development of relocation sites that catered to displaced families from Quezon City and other cities surrounding the Pasig river. Kasiglahan Village is one example of these developments, with residents mostly relocated from Quezon City areas. [22]

There are several health facilities within Rodriguez Rizal. The Rural Health Unit is manned by the rural health officer, physicians, nurses, midwives, sanitary inspectors and malaria officers. There is a 25 -bed infirmary (Montalban Infirmary) that is located in Kasiglahan Village and a government health facility (Casimiro Ynares Sr. Memorial Hospital). Other private health providers likewise exist which include hospitals, lying-in clinics and multi-specialty clinics. Each barangay has at least one health center with some having satellite health centers. Hospitals outside of the municipality are also easily accessible through jeepneys and other public utility vehicles. Based on the interviews with the residents and health workers from Kasiglahan Village, patients needing tertiary care are usually brought to hospitals in Metro Manila such as East Avenue Medical Center in Quezon City and Amang Rodriguez Memorial Medical Center in Marikina City. These hospitals are what they deem as the most accessible and capable of providing higher level of healthcare.

Munting llaw Health Center is a satellite health center of Barangay San Jose and is located in Kasiglahan Village. It is tasked to provide basic health services to the residents of Kasiglahan Village such as maternal and child health, family planning, immunization, and nutrition. It also houses a directly observed treatment short-course (DOTS) clinic for the management of tuberculosis. It is manned by nurses, midwives, barangay health workers, municipal health workers and volunteers.

The leading causes of morbidity in Rodriguez Rizal in 2012 include: 1. Animal Bite; 2. Acute upper respiratory tract infection; 3. Pulmonary tuberculosis; 4. Dengue; 5. Asthma; 6. Acute rhinitis; 7. Acute gastroenteritis; 8. Hypertension; 9. Body injuries and 10. Pharyngitis. Mortalities are mostly due to cardiac causes such as myocardial infarction. Other causes of death include community acquired pneumonia, cancer (mostly of the lung), intra-cerebral hemorrhage, pulmonary tuberculosis and non-disease related deaths due to body injuries and gunshot wounds. [22]

\section{Tobacco cessation services and policies in the community}

None of the existing health facilities within the municipality have an existing tobacco cessation service and there is no smoking cessation clinic anywhere in the municipality and in nearby areas. The municipality has a newly drafted tobacco-free resolution; however, it has not been fully implemented at the time of the implementation of this project. There is an existing ordinance prohibiting smoking in public spaces. This is strictly implemented in the city proper and major establishments but not so much in the communities.

\section{Tobacco interventions from the perspective of health workers.}

The FGD was attended by 24 health workers. The goal of the discussion was to determine the general perception of the workers on smoking cessation interventions and the usual practices in the health center in order to identify possible strategies to integrate $\mathrm{BTI}$ in their existing programs.

None of the health workers had attended any seminar on or related to BTI. Advise on smoking cessation and inquiry regarding the smoking status is not customarily done in any of the existing programs of the health center, except in the TB Directly Observed Treatment Short-Course (TBDOTS) clinic wherein the smoking status of each patient is included in the patient's record. Even so, giving advice is done inconsistently.

Most did not know that BTI can be integrated in all of their programs and only a few recognized the relevance of BTI in their particular line of work (i.e. family planning, nutrition). None were aware of the existence of the National Quitline and no referral mechanism to cessation providers exists.

\section{Understanding the perspective of current smokers.}

FGDs were done to better understand the predicament of smokers in the community. FGDs were done instead of formal interviews with structured questionnaire to allow free flow of thoughts and ideas and thereby be able to capture aspects that are not obtained by the Philippine Global Adult Tobacco Survey (GATS).

Most of the participants initiated their smoking habit during their teen years and curiosity was the 
most common reason for trying. Most had the initial intention to just satisfy their curiosity but eventually got hooked to habit. One of the participants started using chewed tobacco at the age of five. Her parents were tobacco farmers and it was customary for them to chew tobacco leaves while farming. She transitioned to cigarette smoking during her teen years and maintained the smoking habit until adulthood. All of them agreed that it was easy to initiate and maintain the smoking habit because tobacco products were widely available, easily accessible and, at the time of their smoking initiation, very affordable. They are aware of the ill-effects of tobacco on their health, however, there is a general perception that these ill-effects are unlikely to happen to them. And if it does, they are resigned to accept it as an inevitable consequence of their smoking habit. Most are willing to quit "when it is absolutely necessary", however, they do not foresee that they will be able to do so in the near future. This implies that the motivation to quit is generally low. When asked about possible motivations for them to quit, answers included: further price increase in tobacco products, development of health complications and total smoking ban. Tobacco products are also prioritized over other necessities such that they will go to the extent of borrowing money or forego one meal in order to sustain the smoking habit. There is a deep understanding of the current tobacco control policies and the intentions of such policies. However, these did not seem to deter the smoking habit as they were able to adapt to these policies. The smoking ban is not strictly enforced in the community; hence they are able to smoke freely while they are in the community. When going to the city proper or while at work where smoking ban is strictly enforced, they are able to decrease their cigarette consumption. The graphic health warnings on cigarette packages was likewise not enough to dissuade them from smoking because they usually buy individual sticks instead of packs. Others cover graphic warnings in the packaging while some think that the pictures are not real and were only meant to scare them. None of the participants had ever received advice from health workers but most of them will likely avail of smoking cessation services if it is available in the community. None were aware of the National Quitline and most are quite skeptic if it is functional.

\section{Lessons from the former smokers.}

Similar to the FGDs with smokers, the questions during the discussions with former smokers revolved around the initiation of the smoking habit, knowledge of the ill effects of tobacco and views on current national and local tobacco control policies and how it influenced their quit journey. In addition to these, the discussion also focused on the motivation/s for quitting and the challenges encountered during their quit journey.

The common motivation to quit was health reasons since all of the participants were diagnosed with a tobacco-related illness that led to the decision to quit. Most of the participants were only given very brief advice by their physicians and all were able to quit completely, unassisted ("cold turkey" style), and without using any pharmacologic treatment for tobacco dependence. The biggest challenge for most of them was seeing other people smoke, especially during gatherings and special occasions. The urge to relapse into the smoking habit was easier to resist after a few weeks of being tobaccofree. Although they fully support the existing tobacco control policies, most claim that it had little impact on their motivation to quit. The graphic health warnings had some influence in their decision to quit, but seeing real patients with tobacco related illnesses on TV was a stronger motivation for them. When asked about their views on providing cessation services in the health center, most deemed it unnecessary since smokers will quit unassisted for as long as they are motivated. To encourage smokers to quit, they think that it is important to find the right motivation because it is easier to quit when the motivation is strong.

\section{Protecting the non-smokers.}

The discussions with non-smokers, particularly the ones who are exposed to second-hand smoke in their homes, focused on questions about their feelings about the smoking behavior of their loved ones or household members and how they think it will affect them and the other members of the family. The participants were also asked how they deal with the smoking behavior of the household member/s.

Most of the participants were spouses of smokers. All of the participants do not condone the smoking behavior of their spouses; however, they feel that 
their sentiments and objections to the smoking habit are being disregarded. They are fearful of the illeffects of smoking to the health of their spouses and their children as well. As most of their spouses are breadwinners, the smoking habit is a source of anxiety and worry about the future of the family should their spouse develop a tobacco related illness. Unfortunately, these feelings of fear, apprehension and anxiety are often invalidated. Attempts to encourage the spouses to quit smoking are seldom done because discussions on the need to quit often leads to disagreement and tension in the household. Most of the participants are aware of the ill-effects of second-hand smoke, but they are not aware of thirdand fourth-hand smoke. They are receptive of the idea of having a cessation service in the community, however, they are not sure if their spouses will avail of the service or comply with the recommendations.

\section{B. Brief Tobacco Intervention Seminar And Workshop}

At the start of the training, each of the participants were asked to write their job designation, job description and their perceived role in tobacco control. Most of the participants recognized their role as a source of information while a few recognized that they can be role models. The other roles that they can assume in tobacco control were discussed during the training. The first session consisted of modules 1 and 2 and was given mostly in a lecture format. This involved discussions on the mechanism of nicotine addiction, harms of tobacco, benefits of quitting, common misconceptions and the general approach to BTI. The second session consisted of Modules 3 to 5 and involved a discussion of the specific steps in giving brief tobacco intervention. An algorithm on how to approach each patient at various stages of quitting was presented in a workshop format wherein a video demonstration was presented after each lecture and the participants were asked to present a return demonstration. Feedback was given by the facilitator and also solicited from the rest of the audience. At the end of the session, the importance of a referral system to smoking cessation providers and clinics was discussed. Since there is no existing referral mechanism yet in the community, the participants were asked to brainstorm on the possible referral mechanism specifically in Rodriguez Rizal. These mechanisms were presented to the whole group and they were made to choose the most feasible, efficient and plausible mechanism. A pre- and posttest was also done evaluate the effectiveness of the training in terms of improving knowledge. Out of the 34 attendees, only 25 were able to accomplish both the pre- and post-test. It was evident that after the workshop, the mean test scores of the participants significantly improved $(p<0.001)$. At an average, their test score increased by 2.08 points which translates to a $20.8 \%$ increase in baseline knowledge (95\% Cl: 1.35 to 2.81 ). To somehow ensure that the knowledge will be translated into practice, posters, guide cards and education materials were given to the health center and rural health unit (Appendix C).

\section{Community Health Promotion And Education}

The community health education and promotion was done in conjunction with the health education and promotion activity for non-communicable diseases in the community. The findings in the FGDs were taken into consideration and misconceptions identified were corrected in the lay fora. The activity consisted of short lectures interrupted by games to break monotony and to maximize attention span and retention of concepts. The National Quitline was promoted and participants were encouraged to urge the smokers in the community to utilize this service. Education on how to give very brief advice while avoiding conflicts in doing so was also given. A pre- and post-test was done to measure the effectiveness of the lecture in augmenting the participant's knowledge. Out of the 58 attendees, 37 completed the pre- and post-test. It was evident that after the lecture, the mean test score of the participants significantly improved $(p<0.001)$. At an average, the test scores increased by 2.73 points which translates to a $27.3 \%$ increase in baseline knowledge (95\% Cl: 2.18 to 3.28$)$.

\section{DISCUSSION}

The tobacco quit success rate in the Philippines continue to be dismal despite the government's efforts to curb smoking. Nearly half of smokers who are interested in quitting were not given proper advice by a health care provider. [4] In the community, several factors contribute to this (Figure 1). There is an 


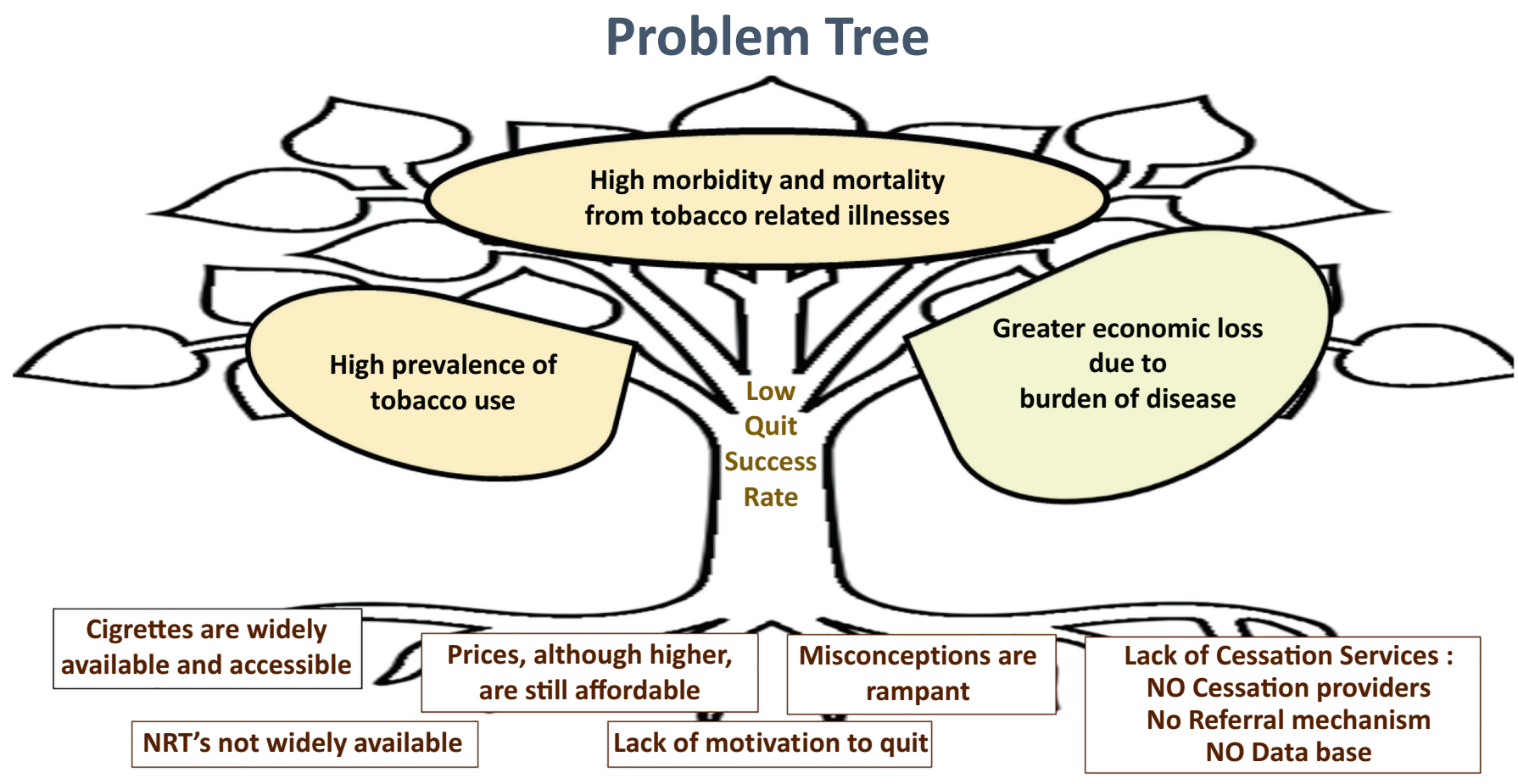

Figure 1 illustrates the problem tree wherein the low quit success rate is identified as the main problem that this project sought to address. The roots represent the factors that contribute to the problem while the branches represent the complications or effects of the main problem.

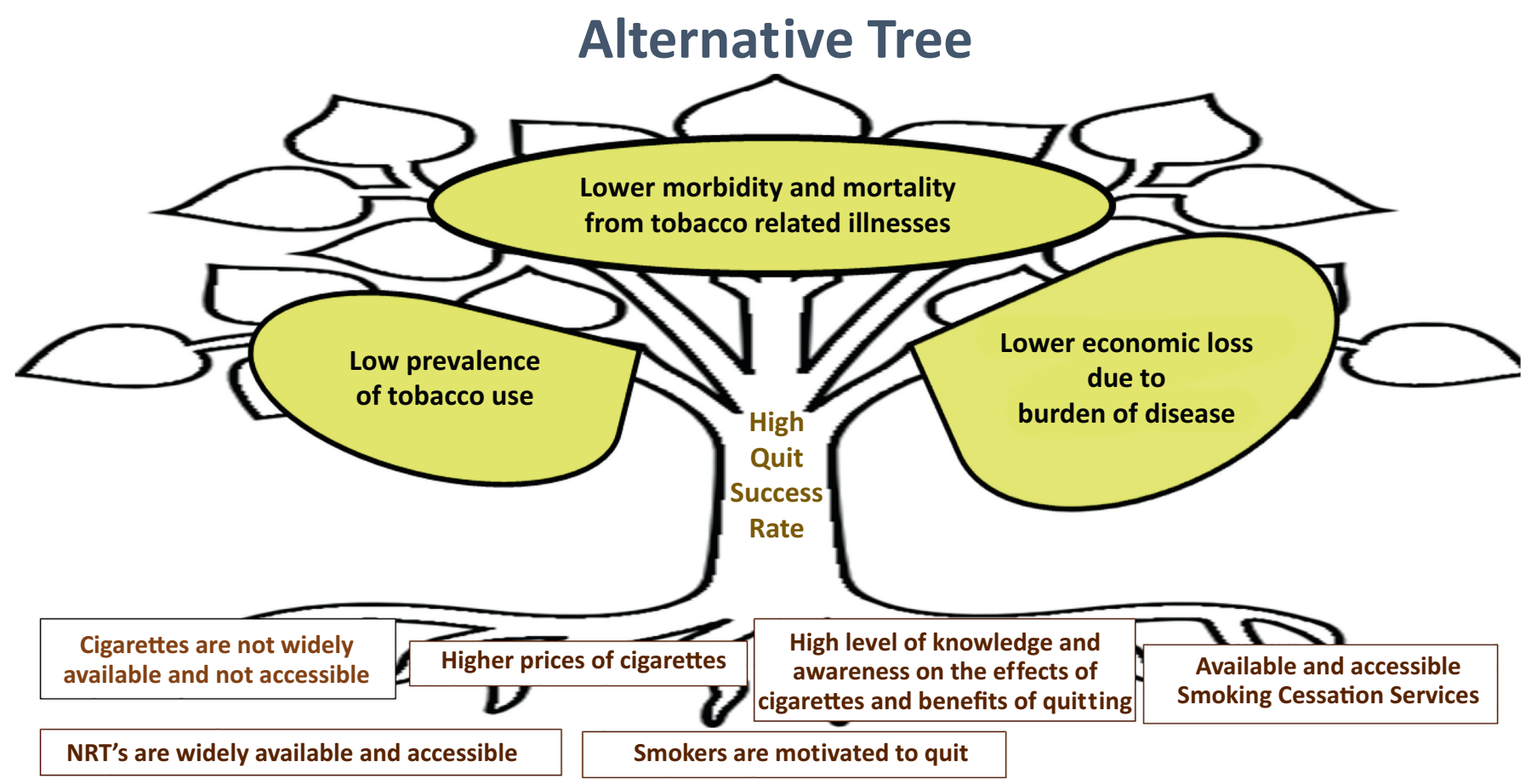

Figure 2 The alternative tree shows the contrast of the problem tree wherein the problem is converted into a positive outcome. The roots represent the factors that can contribute to the realization of this positive outcome and therefore the cascade of negative effects is prevented.

apparent lack of cessation services. Health workers are not trained on brief tobacco intervention and a referral system to cessation support services is not in place. Misconceptions on tobacco cessation is also rampant even among health workers. Like in the rest of the country, tobacco products are widely available and easily accessible. On the contrary, access to nicotine replacement therapies is limited. The prices of cigarettes, even with the surge due to the sin tax law, are still affordable. There is an apparent lack 


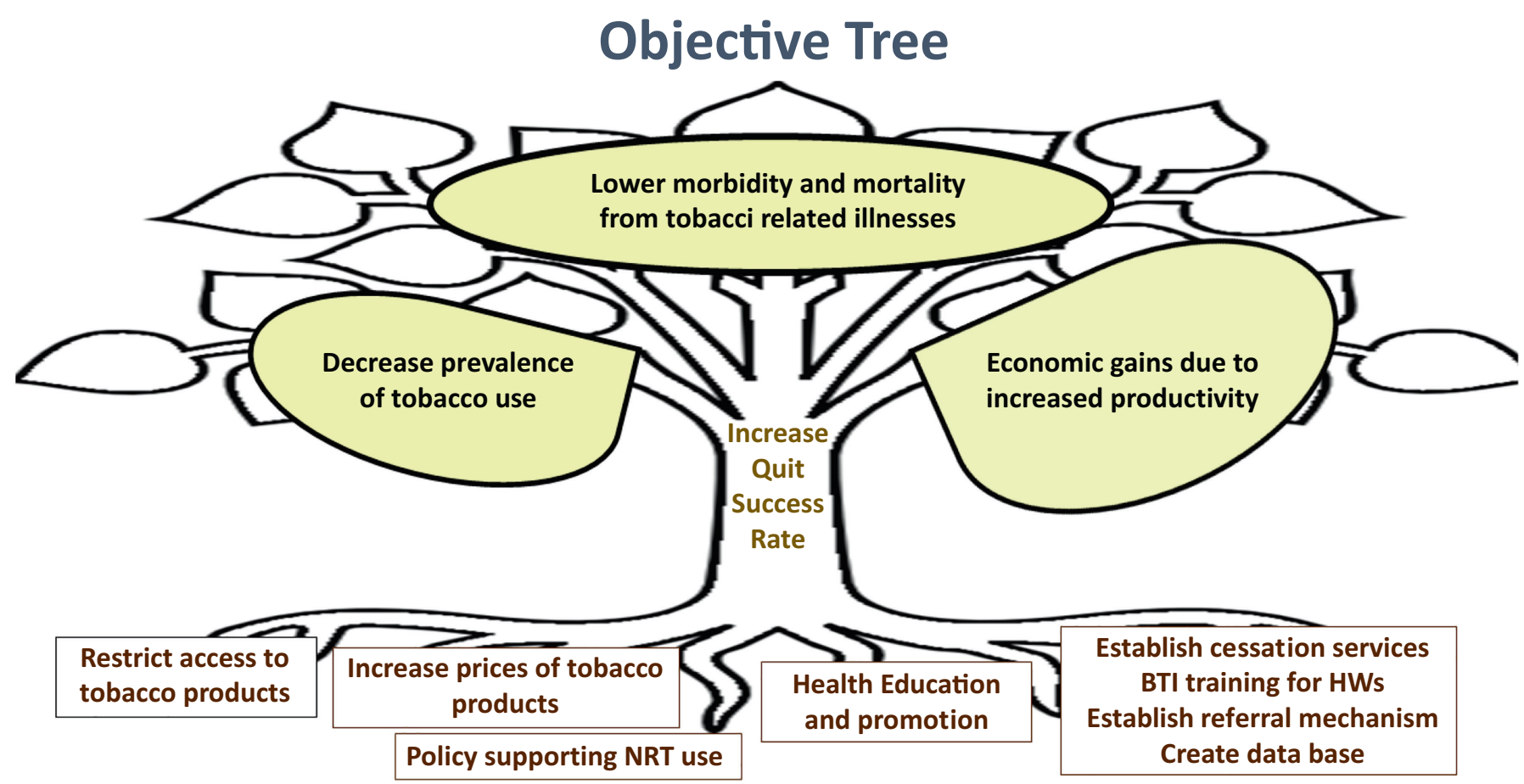

Figure 3 The objective tree represents the possible solutions to the problems identified. The main objective of this project is to increase the quit success rate in the community. The roots represent the interventions that can help realize the objective.

of motivation for smokers to quit despite the graphic warnings and other policies that restrict access to tobacco products and decrease opportunity to smoke. Although a smoking ban exist, this is not uniformly enforced. These factors all contribute to the problem which is a low quit success rate. This in turn result to a myriad of complications such as high prevalence of smoking, high mortality and morbidity from tobacco related illnesses, ultimately leading to greater economic cost.

The objective tree (Figure 3) represents the possible solutions to the problems identified. The outcome that this project envisions is a high quit success rate in the community. However, not all of the interventions identified can be accomplished by this project. Restrictions to tobacco products, price increase and policies on the use of nicotine replacement therapies would need to be addressed by national and/or local government programs and policies. Instead, this project focused on community-based interventions such as the establishment of smoking cessation intervention and referral mechanism in the community health center and health education and promotion activities in the community.

In 2003, the Philippines, being a member of the WHO Western Pacific region, was required to implement the strategies in the WHO Framework Convention on Tobacco Control (FCTC). Bourne from this treaty, the Philippines drafted its National Tobacco Control Strategy (NTSC) for the years 2011-2016. It's three main strategies focused on: 1. Promotion and advocacy for the complete implementation of the FCTC; 2 . Mobilization for public action; and 3. Strengthening the organization capacity. [23] This project is consistent with the activities specified under strategy 3 namely: human resource development, smoking cessation and tobacco dependence treatment, public awareness and education. Likewise, it is consistent with one of the social sectoral objectives of the municipality which is "to implement sustainable preventive healthcare programs to lessen incidence of diseases caused by unhealthy lifestyle". [22]

\section{CONCLUSION AND RECOMMENDATIONS}

The tobacco problem is centuries old and cannot be solved overnight. It is indeed complex and full of challenges. It was found in the situational analysis that the smoking habit can be initiated at the age of five. This means that tobacco use is not freely chosen and therefore there is a need to alter the general environment through interventions that target the wider determinants of health. Such policies already exist; however, it is essential to strengthen these policies and complement it with clinical 
interventions. According to the European Society of Respirology [24], in order to achieve a smoke-free society, tobacco cessation should be supported from policy to clinical perspective. Community based interventions have been consistently shown to be effective in improving quit success rates. Although establishing a formal smoking cessation clinic in the community is ideal, the task may be challenging in a low resource setting as it will entail additional resources. Providing training to the existing health workforce and integrating brief tobacco intervention with the existing programs of the community health center may be more feasible. Likewise, creating a referral mechanism to smoking cessation providers and clinics may augment the efficiency of smoking cessation efforts in the community.

The project aimed to address the clinical aspect of tobacco control by establishing tobacco cessation services in the community. This pilot project has shown that providing brief tobacco training among health workers is feasible. There is a need to assess whether this knowledge is translated into practice and whether the training created attitudinal change as well.

\section{Recommendations}

It is important that tobacco control remain a priority despite the countless other health problems that need attention. Especially because 5 out of the top 10 causes of mortality in the municipality are tobacco related and 4 out of the 5 causes of mortality are due to tobacco related diseases [22]. A local smoke-free policy is essential and its prompt implementation is encouraged. Stricter and consistent enforcement of the smoking ban is likewise encouraged. Continued health education is necessary to contradict misconceptions on tobacco cessation. BTI training should likewise be cascaded in other health centers, with priority given to at least the head nurse and TB-DOTS nurses. Regular updating of the seminar, on a yearly or every two years basis, is likewise necessary. Once smoking cessation services are fully integrated in the programs of the health centers and more cessation providers are available, smoking cessation clinics in key institutions in the municipality can be established. In the meantime, while smoking cessation clinics are not yet available in the municipality, it is recommended to promote the use of the National Quitline.

\section{Limitations}

Tobacco control is multi-faceted and this project mainly focused on the clinical aspect. Although an increase in the knowledge of the participants was documented, whether this knowledge was translated into practice was not assessed. Measuring the impact of the project in terms of increasing quit success rate is likewise ideal but beyond the scope of the project.

\section{Conflict of Interest Statement}

The project was conducted in the absence of any commercial or financial relationships that could be construed as a potential conflict of interest.

Ethics Approval and Consent to Participate

Not applicable.

\section{Acknowledgement}

The authors would like to acknowledge the people and institutions that were instrumental in the accomplishment of this project.

- For their assistance, insights and valuable inputs: Honorable Glenn Evangelista, Chairman of Barangay San Jose

Dr. Ma. Carmela V. Javier, Municipal Health Officer of Rodriguez Rizal

Community leaders of Phase 1K, Barangay Kasiglahan, Rodriguez Rizal

Dr. Leilani B. Mercado-Asis, Program Head, Master in Public Health (International), UST Faculty of Medicine and Surgery

- For providing the module for Brief Tobacco Intervention Training and health promotion and education materials:

Philippine College of Chest Physicians, Council on Control for Tobacco and Air Pollution

Dr. Glynna Ong-Cabrera, Chairperson

Dr. Marie Charisma Dela Trinidad

Ms. Riza SJ San Juan, RN, Nurse Coordinator, Smoking Cessation Program, Lung Center of the Philippines

Counselors and staff of the DOH National Quitline

- For their unwavering support throughout the conduct of this project from its conception to its realization:

UST FMS Master in Public Health (International) classmates and mentors 


\section{REFERENCES}

1. World Health Organization. WHO Tobacco Fact Sheet 2019. [Internet]. 2019 [cited 04 April 2019]. Available from: https://www.who.int/news-room/fact-sheets/detail/ tobacco

2. World Health Organization. WHO global report on trends in prevalence of tobacco smoking. [Internet]. 2015 [cited 04 April 2019]. Available from: https://apps.who.int/iris/bitstream/ handle/10665/156262/9789241564922_eng.pdf;jisessioni $\mathrm{d}=8 \mathrm{FA} 5678 \mathrm{C} 2197750 \mathrm{E} 092 \mathrm{EFFACF9FDOFOE}$ ? sequence $=$

3. Philippine Statistics Authority. Registered Deaths in the Philippines, 2017. [Internet]. 2019 [cited 08 January 2020]. Available from: https://psa.gov.ph/vital-statistics/ id/138794

4. Department of Health Philippines. Global Adult Tobacco Survey: Philippine Country Report, 2015. [Internet]. 2015 [cited 08 April 2019]. Available from: https://www.who.int/ tobacco/surveillance/survey/gats/phl_country_report.pdf

5. World Health Organization Tobacco Free Initiative. Strengthening health systems for treating tobacco dependence in primary care. Building capacity for tobacco control: training package. [Internet]. 2013 [cited 05 January 2020]. Available from: https://www.who.int/tobacco/publications/building capacity/training_package/treatingtobaccodependence/ en/

6. Ayo-Yusuf O, Szymanski B. Factors associated with smoking cessation in South Africa. South African Medical Journal [Internet]. 2010;100(3):175-9. Available from: http://www. samj.org.za/index.php/samj/article/view/3842

7. Lee C, Kahende J. Factors Associated With Successful Smoking Cessation in the United States, 2000. Am J Public Health [Internet]. 2007 Aug;97(8):1503-9. Available from: http:// dx.doi.org/10.2105/AJPH.2005.083527

8. Yeom H, Lim H-S, Min J, Lee S, Park Y-H. Factors Affecting Smoking Cessation Success of Heavy Smokers Registered in the Intensive Care Smoking Cessation Camp (Data from the National Tobacco Control Center). Osong Public Health Res Perspect [Internet]. 2018 Oct $31 ; 9(5): 240-7$. Available from: http://dx.doi.org/10.24171/i.phrp.2018.9.5.05

9. Azevedo RCS de, Fernandes RF. Factors relating to failure to quit smoking: a prospective cohort study. Sao Paulo Med J [Internet]. 2011 Dec;129(6):380-6. Available from: http:// dx.doi.org/10.1590/s1516-31802011000600003

10. Kim Y, Cho W-K. Factors associated with successful smoking cessation in Korean adult males: Findings from a national survey. Iran J Public Health. 2014;43(1 1):1486-96.

11. Khati I, Menvielle G, Chollet A, Younès N, Metadieu B, Melchior $M$. What distinguishes successful from unsuccessful tobacco smoking cessation? Data from a study of young adults (TEMPO). Preventive Medicine Reports [Internet]. 2015;2:679-85. Available from: http://dx.doi. org/10.1016/i.pmedr.2015.08.006

12. Bacha ZA, Layoun $N$, Khayat $G$, Hallit $S$. Factors associated with smoking cessation success in Lebanon. Pharm Pract (Granada) [Internet]. 2018 Mar 31;16(1):1111. Available from: http://dx.doi.org/10.18549/PharmPract.2018.01.1111

13. Holm M, Schiöler L, Andersson E, Forsberg B, Gislason T, Janson $C$, et al. Predictors of smoking cessation: A longitudinal study in a large cohort of smokers. Respiratory Medicine [Internet]. 2017 Nov;132:164-9. Available from: http:// dx.doi.org/10.1016/j.rmed.2017.10.013

14. DiGiacomo M, Davidson P, Abbott P, Davison J, Moore L, Thompson S. Smoking Cessation in Indigenous Populations of Australia, New Zealand, Canada, and the United States: Elements of Effective Interventions. IJERPH [Internet]. 2011 Jan 31;8(2):388-410. Available from: http://dx.doi. org/10.3390/ijerph8020388

15. Estreet A, Apata J, Kamangar F, Schutzman C, Buccheri J, $\mathrm{O}^{\prime}$ Keefe $A-M$, et al. Improving participants' retention in a smoking cessation intervention using a community-based participatory research approach. Int J Prev Med. 2017;8:106.

16. Asvat Y, Cao D, Africk JJ, Matthews A, King A. Feasibility and Effectiveness of a Community-Based Smoking Cessation Intervention in a Racially Diverse, Urban Smoker Cohort. Am J Public Health [Internet]. 2014 Sep;104(S4):S620-7. Available from: http://dx.doi.org/10.2105/AJPH.2014.302097

17. Levinson AH, Valverde P, Garrett K, Kimminau M, Burns EK, Albright $\mathrm{K}$, et al. Community-based navigators for tobacco cessation treatment: a proof-of-concept pilot study among low-income smokers. BMC Public Health [Internet]. 2015 Jul 9;15(1). Available from: http://dx.doi.org/10.1186/ s12889-015-1962-4

18. Li WHC, Chan SSC, Wan ZSF, Wang MP, Ho KY, LAM TH. Development of a community-based network to promote smoking cessation among female smokers in Hong Kong. BMC Public Health [Internet]. 2017 Apr 11;17(1). Available from: http://dx.doi.org/10.1186/s1 2889-017-4213-z

19. Matthews AK, Li C-C, Kuhns LM, Tasker TB, Cesario JA. Results from a Community-Based Smoking Cessation Treatment Program for LGBT Smokers. Journal of Environmental and Public Health [Internet]. 2013;2013:1-9. Available from: http:// dx.doi.org/10.1155/2013/984508

20. Whitehouse E, Lai J, Golub JE, Farley JE. A systematic review of the effectiveness of smoking cessation interventions among patients with tuberculosis. Public Health Action. 2018;8(2):37-49.

21. Department of Health. Brief Tobacco Intervention Training Module: October 2019; unpublished.

22. Municipality of Rizal. Situational Analysis Report: 2013;unpublished.

23. Department of Health, Philippines. Philippine National Tobacco Control Strategy. [Internet]. 2011 [cited 22 May 2019]. Available from: https://www.doh.gov.ph/sites/ default/files/publications/NationalTobaccoControlStrategy\% 28NTCS\%29.pdf

24. Fu D, Gratziou C, Jiménez-Ruiz C, Faure M, Ward B, Ravara $\mathrm{S}$, et al. The WHO-ERS Smoking Cessation Training Project: the first year of experience. ERJ Open Res [Internet]. 2018 Jul;4(3):00070-2018. Available from: http://dx.doi. org/10.1183/23120541.00070-2018

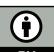

Open Access This article is licensed under a Creative Commons Attribution 4.0 International License, which permits use, sharing, adaptation, distribution and reproduction in any medium or format, as long as you give appropriate credit to the original author(s) and the source, provide a link to the Creative Commons license, and indicate if changes were made. The images or other third party material in this article are included in the article's Creative Commons license, unless indicated otherwise in a credit line to the material. If material is not included in the article's Creative Commons license and your intended use is not permitted by statutory regulation or exceeds the permitted use, you will need to obtain permission directly from the copyright holder. To view a copy of this license, visit http://creativecommons.org/licenses/by/4.0/. 


\section{APPENDICES}

\section{APPENDIX A: SUMMARY OF REVIEW OF RELATED LITERATURE}

Table 1. Summary of Studies on Factors Associated with Quit Outcomes

\begin{tabular}{|c|c|c|c|c|c|}
\hline $\begin{array}{l}\text { TITLE, AUTHOR/S, DATE } \\
\text { OF PUBLICATION }\end{array}$ & OBJECTIVES & METHODOLOGY & $\begin{array}{c}\text { POPULATION } \\
\text { AND SAMPLE } \\
\text { SIZE }\end{array}$ & KEY FINDINGS & LIMITATIONS \\
\hline $\begin{array}{l}\text { 1. Factors associated } \\
\text { with smoking } \\
\text { cessation in South } \\
\text { Africa } \\
\text { Authors: } \\
\text { Olalekan A Ayo-Yusuf, } \\
\text { Ben Szymanski } \\
\text { Year of Publication: } \\
2010\end{array}$ & $\begin{array}{l}\text { To determine } \\
\text { the factors } \\
\text { associated with } \\
\text { attempting to } \\
\text { quit smoking } \\
\text { and successfully } \\
\text { doing so, } \\
\text { among South } \\
\text { Africans. }\end{array}$ & Cross-sectional & $\begin{array}{l}\text { N=12, } 481 \\
\text { South African } \\
\text { Adults } \\
\text { Data from } \\
1998 \text { South } \\
\text { African } \\
\text { Demographic } \\
\text { Survey }\end{array}$ & $\begin{array}{l}\text { Quit Attempt rate: } \\
68.1 \% \\
\text { Quit Success rate: } \\
14.1 \% \\
\text { Factors associated } \\
\text { with quit success: } \\
\text { - Female } \\
\text { - > } 55 \text { y/o } \\
\text { - } 1 \text { to } 7 \text { years of } \\
\text { schooling } \\
\text { - Currently dependent }\end{array}$ & $\begin{array}{l}\text { Data set is from } \\
1998 \\
\text { Cross-sectional } \\
\text { possibility of } \\
\text { reverse causation } \\
\text { of the observed } \\
\text { effects. } \\
\text { Smoking and } \\
\text { drinking habits } \\
\text { were assessed } \\
\text { by self-report } \\
\text { only }\end{array}$ \\
\hline $\begin{array}{l}\text { 2. Factors Associated } \\
\text { with Successful } \\
\text { Smoking } \\
\text { Cessation in the } \\
\text { United States, } \\
\mathbf{2 0 0 0} \\
\text { Authors: } \\
\text { Chung-won Lee, PhD, MA, } \\
\text { and } \\
\text { Jennifer Kahende, PhD } \\
\text { Year of Publication: } \\
2007\end{array}$ & $\begin{array}{l}\text { To identify } \\
\text { factors } \\
\text { associated } \\
\text { with successful } \\
\text { quitting so } \\
\text { that cessation } \\
\text { programs could } \\
\text { be tailored to } \\
\text { those at highest } \\
\text { risk for relapse. }\end{array}$ & Cross-sectional & $\begin{array}{l}\mathrm{N}=3,990 \\
\text { Adult US } \\
\text { citizens } \\
\text { Data from } \\
2000 \text { National } \\
\text { Health } \\
\text { Interview } \\
\text { Survey }\end{array}$ & $\begin{array}{l}\text { Quit attempt rate: } \\
40 \% \\
\text { Quit success rate: } \\
\text { < } 10 \% \\
\text { Factors associated } \\
\text { with quit success: } \\
\text { - Rules against } \\
\text { smoking at home } \\
\text { - >35 y/o } \\
\text { - Married or living } \\
\text { - with a partner } \\
\text { - Non- } \\
\text { - Hispanic white } \\
\text { - College education }\end{array}$ & $\begin{array}{l}\text { Cross-sectional } \\
\text { nature of the } \\
\text { study } \\
\text { Survey is limited } \\
\text { to civilian, non- } \\
\text { institutionalized } \\
\text { US citizens } \\
\text { Smoking and } \\
\text { drinking habits } \\
\text { were based on } \\
\text { self-report only } \\
\text { No data on } \\
\text { the number } \\
\text { of cigarettes } \\
\text { smoked by } \\
\text { former smokers }\end{array}$ \\
\hline $\begin{array}{l}\text { 3. Factors Associated } \\
\text { with Successful } \\
\text { Smoking } \\
\text { Cessation in } \\
\text { Korean Adult } \\
\text { Males: Findings } \\
\text { from a National } \\
\text { Survey }\end{array}$ & $\begin{array}{l}\text { To explore } \\
\text { the fac- tors } \\
\text { associated } \\
\text { with successful } \\
\text { smoking } \\
\text { cessation } \\
\text { among South } \\
\text { Korean adult } \\
\text { males. }\end{array}$ & Cross-sectional & $\begin{array}{l}\mathrm{N}=7,839 \\
\text { Korean males, } \\
\text { aged 19-65 } \\
\text { years } \\
\text { Data from } \\
\text { Korea National } \\
\text { Health and } \\
\text { Nutrition } \\
\text { Examination } \\
\text { Survey } \\
\text { (KNHANES) } \\
\text { from } 2007 \text { to } \\
2012\end{array}$ & $\begin{array}{l}\text { Quit success rate: } \\
45.5 \% \\
\text { Factors associated } \\
\text { with quit success: } \\
\text { - Older age } \\
\text { - Marriage } \\
\text { - Higher income } \\
\text { - Smoking larger } \\
\text { amounts } \\
\text { - Use of will power } \\
\text { - Alcohol abstinence } \\
\text { - Cancer history } \\
\text { - Better mental health } \\
\text { - Higher quality of } \\
\text { life }\end{array}$ & $\begin{array}{l}\text { Cross-sectional } \\
\text { nature of the } \\
\text { study } \\
\text { Data on the } \\
\text { duration of } \\
\text { abstinence is not } \\
\text { available } \\
\text { Homogenous } \\
\text { population }\end{array}$ \\
\hline
\end{tabular}


Table 1. Summary of Studies on Factors Associated with Quit Outcomes (Continued)

\begin{tabular}{|c|c|c|c|c|}
\hline $\begin{array}{l}\text { TITLE, AUTHOR/S, DATE } \\
\text { OF PUBLICATION }\end{array}$ & OBJECTIVES & METHODOLOGY & $\begin{array}{c}\text { POPULATION } \\
\text { AND SAMPLE } \\
\text { SIZE }\end{array}$ & KEY FINDINGS \\
\hline
\end{tabular}

4. What
distinguishes
successful from
unsuccessful
tobacco smoking
cessation? Data
from a study of
young adults
(TEMPO)

Authors: Inès Khati, Gwenn Menvielle,

Aude Chollet,

Nadia Younès,

Brigitte Metadieu,

Maria Melchior

Year of Publication:

2015

\section{Factors Affecting Smoking \\ Cessation Success \\ of Heavy Smokers \\ Registered in \\ the Intensive \\ Care Smoking \\ Cessation Camp \\ (Data from the \\ National Tobacco \\ Control Center)}

Authors: Hansol Yeom, Hee-Sook Lim, Jihyun Min, Seoni Lee, YoonHyung Park

Year of Publication: 2018

6. Factors associated with smoking cessation success in Lebanon

\section{Authors:}

Zeina A. Bacha,

Nelly Layoun, Georges

Khaya, Souheil Hallit

Year Published: 2018

\begin{abstract}
To compare
individuals who

successfully

quit smoking

from those

who relapsed

on socio-

demographic,

psychological

and health

factors
\end{abstract}

Cross-sectional

$N=600$ young
adults aged 18
to 37 in France

to 37 in France

Data come - parental status

from telephone - illegal drug use

interviews

conducted in

2011 with

participants

of the TEMPO

community-

based study

Factors associated

To investigate

the factors

involved in

the success

of smoking

cessation in

heavy smokers

enrolled in

an intensive

care smoking

cessation camp

program.

Cross-sectional
Cross-sectional
Con

To assess factors associated with the success rate of smoking cessation among

Lebanese

smokers in

a smoking

cessation center.

\begin{tabular}{|c|c|}
\hline $\begin{array}{l}\mathrm{N}=98 \text { heavy } \\
\text { smokers }\end{array}$ & $\begin{array}{l}\text { Quit success rate: } \\
98 \%\end{array}$ \\
\hline $\begin{array}{l}\text { enrolled in } \\
\text { an intensive } \\
\text { care smoking } \\
\text { cessation camp }\end{array}$ & $\begin{array}{l}\text { Factors associated } \\
\text { with quit success: }\end{array}$ \\
\hline program in & - Married \\
\hline South Korea & $\begin{array}{l}\text { - More frequent } \\
\text { counselling sessions }\end{array}$ \\
\hline $\begin{array}{l}\text { Data from } \\
\text { the National }\end{array}$ & $\begin{array}{l}\text { - Higher education } \\
\text { level }\end{array}$ \\
\hline
\end{tabular}

Tobacco

Control Center

Factors NOT

associated with

success:

- Level of nicotine dependence

- Gender

$N=156$

patients enrolled in an outpatient smoking cessation center in Lebanon

Factors associated with quit success:

- Compliance with offered treatment

- Highly motivated

- Highly dependent with a low probability

of smoking cessation:

- job strain

- symptoms of hyperactivity/ inattention

Cross-sectional nature of the study

Participants' nicotine dependence was not assessed

Study population had more favorable socioeconomic circumstances than the general population of France

Data cannot be generalized because the population used was very specific.
Cross-sectional design

Total sample size is small

Selection bias is possible because of the refusal rate

Use of a questionnaire may not always be accurate

Relied on selfreported data 
Table 1. Summary of Studies on Factors Associated with Quit Outcomes (Continued)

\begin{tabular}{|c|c|c|c|c|c|}
\hline $\begin{array}{l}\text { TITLE, AUTHOR/S, DATE } \\
\text { OF PUBLICATION }\end{array}$ & OBJECTIVES & METHODOLOGY & $\begin{array}{c}\text { POPULATION } \\
\text { AND SAMPLE } \\
\text { SIZE }\end{array}$ & KEY FINDINGS & LIMITATIONS \\
\hline $\begin{array}{l}\text { 7. Predictors } \\
\text { of smoking } \\
\text { cessation: A } \\
\text { longitudinal study } \\
\text { in a large cohort } \\
\text { of smokers } \\
\text { Authors: } \\
\text { Mathias Holm, Linus } \\
\text { Schiöler, Eva Andersson, } \\
\text { Bertil Forsberg, } \\
\text { Thorarinn Gislason, } \\
\text { Christer Janson, Rain }\end{array}$ & $\begin{array}{l}\text { To study the } \\
\text { smoking } \\
\text { cessation rate } \\
\text { in relation to } \\
\text { several potential } \\
\text { predictors, with } \\
\text { special focus on } \\
\text { respiratory and } \\
\text { cardiovascular } \\
\text { disease. }\end{array}$ & $\begin{array}{l}\text { Prospective } \\
\text { cohort }\end{array}$ & $\begin{array}{l}\mathrm{N}=4,636 \\
\text { born between } \\
1945 \text { and } \\
1973 \text { from } \\
\text { seven centers } \\
\text { in Northern } \\
\text { Europe } \\
\text { (Norway, } \\
\text { Sweden, } \\
\text { lceland, } \\
\text { Denmark, } \\
\text { Estonia) }\end{array}$ & $\begin{array}{l}\text { Quit success rate: } \\
39 \% \\
\text { Factors associated } \\
\text { with quit success: } \\
\text { - Older age } \\
\text { - Higher education } \\
\text { - Fewer years of } \\
\text { smoking } \\
\text { - Hospitalized due } \\
\text { to ischemic heart } \\
\text { disease }\end{array}$ & $\begin{array}{l}\text { Recall bias due } \\
\text { to the use of self- } \\
\text { reported data } \\
\text { Possible risk of } \\
\text { misclassification } \\
\text { since no } \\
\text { biochemical } \\
\text { marker for } \\
\text { smoking } \\
\text { dependence was } \\
\text { used }\end{array}$ \\
\hline
\end{tabular}

Jogi, Vivi Schlünssen,

Cecilie Svanes, Kjell

Toréna

Year of Publication:

2017

8. Factors relating

to failure to quit smoking:

a prospective cohort study

\section{Authors:}

Renata Cruz, Soares de

Azevedo, Rejane Firmino

Fernandes

Year of Publication:

2011 the use of selt-

Possible risk of (1) dependence was

\begin{tabular}{|c|c|c|c|c|}
\hline $\begin{array}{l}\text { To identify } \\
\text { factors relating } \\
\text { to failure of } \\
\text { attempts to } \\
\text { quit smoking } \\
\text { among smokers } \\
\text { who sought } \\
\text { care at an } \\
\text { outpatient clinic } \\
\text { in a general } \\
\text { university } \\
\text { hospital }\end{array}$ & $\begin{array}{l}\text { Prospective } \\
\text { cohort }\end{array}$ & $\begin{array}{l}\mathrm{N}=100 \\
\text { smokers } \\
\text { who sought } \\
\text { treatment at the } \\
\text { Psychoactive } \\
\text { Substances } \\
\text { Outpatient } \\
\text { Clinic in Brazil }\end{array}$ & $\begin{array}{l}\text { Quit success rate: } \\
66 \% \text { among those } \\
\text { who adhered to } \\
\text { treatment; } 17 \% \\
\text { among those who } \\
\text { did not adhere to } \\
\text { treatment } \\
\text { Factors related to quit } \\
\text { failure: } \\
\text { - Without tobacco } \\
\text { related diseases } \\
\text { - Without leisure } \\
\text { - Higher education } \\
\text { level }\end{array}$ & $\begin{array}{l}\text { Small number } \\
\text { of subjects } \\
\text { evaluated } \\
\text { Smoking status } \\
\text { was measured } \\
\text { through self- } \\
\text { reporting, } \\
\text { without } \\
\text { biological } \\
\text { validation } \\
\text { The study was } \\
\text { conducted using } \\
\text { a convenience } \\
\text { sample }\end{array}$ \\
\hline
\end{tabular}

Table 2. Review of Articles on Community-based Smoking Cessation Services

\begin{tabular}{|c|c|c|c|c|}
\hline $\begin{array}{c}\text { TITLE/AUTHOR/YEAR } \\
\text { PUBLISHED }\end{array}$ & OBJECTIVES & METHODS & KEYS FINDINGS & LIMITATIONS \\
\hline $\begin{array}{l}\text { 1. Feasibility and } \\
\text { Effectiveness of a } \\
\text { Community-Based } \\
\text { Smoking Cessation } \\
\text { Intervention in a } \\
\text { Racially Diverse, } \\
\text { Urban Smoker } \\
\text { Cohort } \\
\text { Authors: } \\
\text { Yasmin Asvat, PhD, } \\
\text { Dingcai Cao, PhD, Joel } \\
\text { J. Africk, JD, Alicia } \\
\text { Matthews, PhD, and } \\
\text { Andrea King, PhD } \\
\text { Year Published: } 2014\end{array}$ & $\begin{array}{l}\text { To evaluate } \\
\text { the feasibility, } \\
\text { acceptability, and } \\
\text { effectiveness, in } \\
\text { addition to the effects } \\
\text { of a psychoeducation- } \\
\text { based orientation on } \\
\text { smoking cessation } \\
\text { knowledge for } \\
\text { Courage to Quit } \\
\text { (CTQ). }\end{array}$ & $\begin{array}{l}\text { Prospective } \\
\text { Cohort } \\
\mathrm{N}=1944 \\
\text { Intervention: } \\
\text { evidence-based } \\
\text { smoking cessation } \\
\text { intervention } \\
\text { disseminated to } \\
\text { racially diverse, } \\
\text { urban community } \\
\text { sites in Chicago, } \\
\text { Illinois. }\end{array}$ & $\begin{array}{l}\text { Orientation improved } \\
\text { knowledge of } \\
\text { efficacious and } \\
\text { non-efficacious } \\
\text { treatments. } \\
\text { Acceptability: > 90\% } \\
\text { Feasibility: completion } \\
\text { rates were } 53 \% \text { in the } \\
\text { full and } 75 \% \text { in the } \\
\text { short programs. } \\
\text { Intent-to-treat quit } \\
\text { rates: } 19 \% \text { in the full } \\
\text { and } 17 \% \text { in the short } \\
\text { programs }\end{array}$ & $\begin{array}{l}\text { community partners did } \\
\text { not have the resources } \\
\text { necessary to collect } \\
\text { detailed data. } \\
\text { there was substantial } \\
\text { attrition } \\
\text { relied on self-reports } \\
\text { the long-term } \\
\text { maintenance of smoking } \\
\text { cessation is unknown } \\
\text { beyond the end of } \\
\text { treatment }\end{array}$ \\
\hline
\end{tabular}


Table 2. Review of Articles on Community-based Smoking Cessation Services (Continued)

\begin{tabular}{|c|c|c|c|c|}
\hline $\begin{array}{c}\text { TITLE/AUTHOR/YEAR } \\
\text { PUBLISHED }\end{array}$ & OBJECTIVES & METHODS & KEYS FINDINGS & LIMITATIONS \\
\hline $\begin{array}{l}\text { 2. Results from a } \\
\text { Community-Based } \\
\text { Smoking Cessation } \\
\text { Treatment Program } \\
\text { for LGBT Smokers }\end{array}$ & $\begin{array}{l}\text { To evaluate the } \\
\text { treatment outcomes } \\
\text { associated with a } \\
\text { culturally tailored } \\
\text { smoking cessation } \\
\text { treatment program }\end{array}$ & $\begin{array}{l}\text { Prospective } \\
\text { Cohort } \\
\mathrm{N}=198 \text { LGBT } \\
\text { individuals }\end{array}$ & $\begin{array}{l}\text { Treatment completion } \\
\text { rate: } 42.4 \% \\
\text { Self-reported quit } \\
\text { rates: } 32.3 \%\end{array}$ & $\begin{array}{l}\text { Relied on self-reports } \\
\text { Did not collect any } \\
\text { culturally specific } \\
\text { measures }\end{array}$ \\
\hline $\begin{array}{l}\text { Authors: } \\
\text { Alicia K. Matthews, } \\
\text { Chien-Ching Li, } \\
\text { Lisa M. Kuhns, } \\
\text { Timothy B. Tasker, and } \\
\text { John A. Cesario } \\
\text { Year Published: } 2013\end{array}$ & $\begin{array}{l}\text { for LGBT smokers that } \\
\text { were offered as part } \\
\text { of clinical practice in } \\
\text { a community-based } \\
\text { health center. }\end{array}$ & $\begin{array}{l}\text { Intervention: } \\
\text { group-based } \\
\text { treatment based } \\
\text { on the American } \\
\text { Lung Association's } \\
\text { "Freedom from } \\
\text { Smoking } \\
\text { Program" } \\
\text { (ALA-FFS), tailored } \\
\text { to LGBT smokers' } \\
\text { needs. }\end{array}$ & $\begin{array}{l}\text { Treatment attendance } \\
(O R=2.45) \text {, use of } \\
\text { NRT (OR }=4.24) \text {, and } \\
\text { lower nicotine } \\
\text { dependency } \\
(O R=0.73) \text { were } \\
\text { positively associated } \\
\text { with quitting smoking. }\end{array}$ & $\begin{array}{l}\text { A full battery of } \\
\text { smoking questions was } \\
\text { not included. } \\
\text { No data were available } \\
\text { on longer-term quit rates } \\
\text { associated with the } \\
\text { program. }\end{array}$ \\
\hline $\begin{array}{l}\text { 3. Improving } \\
\text { Participants' } \\
\text { Retention in a } \\
\text { Smoking Cessation } \\
\text { Intervention } \\
\text { Using a } \\
\text { Community-based } \\
\text { Participatory } \\
\text { Research Approach } \\
\text { Authors: } \\
\text { Anthony Estreet, } \\
\text { Jummai Apata, } \\
\text { Farin Kamangar, } \\
\text { Christine Schutzman, } \\
\text { Jane Buccheri, } \\
\text { Anne-Marie O'Keefe, } \\
\text { Fernando Wagner, and } \\
\text { Payam Sheikhattari }\end{array}$ & $\begin{array}{l}\text { To compare } \\
\text { participant's retention } \\
\text { in three phases of } \\
\text { smoking cessation } \\
\text { interventions, one } \\
\text { provided in a health } \\
\text { clinic and the } \\
\text { subsequent two in } \\
\text { community-based } \\
\text { settings. }\end{array}$ & $\begin{array}{l}\text { Prospective } \\
\text { Cohort } \\
\mathrm{N}=951 \\
\text { from two } \\
\text { underserved } \\
\text { urban } \\
\text { communities } \\
\text { with low } \\
\text { socioeconomic } \\
\text { profiles and high } \\
\text { rates of smoking } \\
\text { Phase: clinic } \\
\text { Phases II and III: } \\
\text { community venues }\end{array}$ & $\begin{array}{l}\text { Retention increased } \\
\text { substantially over the } \\
\text { three phases } \\
\text { Phase I: } 13.8 \% \\
\text { Phase II: } 51.9 \% \\
\text { Phase III: } 67.9 \% \\
\text { Retention was } \\
\text { significantly higher in } \\
\text { community settings } \\
\text { than in the clinic } \\
\text { setting (OR = 6.7; } \\
95 \% \\
\mathrm{Cl}=4.6,9.8 \text { ). } \\
\text { Higher retention was } \\
\text { significantly associated } \\
\text { with higher quit rates }\end{array}$ & $\begin{array}{l}\text { Unavailability of some } \\
\text { information. }\end{array}$ \\
\hline
\end{tabular}

Year Published: 2017

\section{A systematic review of the effectiveness of smoking cessation interventions among patients with tuberculosis}

\section{Authors:}

E. Whitehouse, J. Lai, J. E. Golub, J. E. Farley
To consolidate existing evidence on smoking cessation interventions among TB patients in LMICs and summarize the practice, policy, and research implications of these findings to improve smoking cessation efforts.
$\mathrm{N}=14$ articles

form 11

countries between 2007-2017

\section{RCT: 3}

Cluster RCT: 2

Prospective

Cohort: 5

Non-randomized intervention trial: 3
Addition of smoking cessation intervention to routine TB case management is feasible and effective in reducing smoking rates among patients during anti-TB treatment.
Most of the studies included were non-randomized or observational.

Risk of bias was high in many studies.

Sample size is small.

Relied on self-reporting.

Year Published: 2018 
Table 2. Review of Articles on Community-based Smoking Cessation Services (Continued)

\begin{tabular}{|c|c|c|c|c|}
\hline $\begin{array}{c}\text { TITLE/AUTHOR/YEAR } \\
\text { PUBLISHED }\end{array}$ & OBJECTIVES & METHODS & KEYS FINDINGS & LIMITATIONS \\
\hline $\begin{array}{l}\text { 5. Community-based } \\
\text { navigators for } \\
\text { tobacco cessation } \\
\text { treatment: a proof- } \\
\text { of-concept pilot } \\
\text { study among low- } \\
\text { income smokers } \\
\text { Authors: } \\
\text { Arnold H. Levinson, } \\
\text { Patricia Valverde, } \\
\text { Kathleen Garrett, } \\
\text { Michele Kimminau, } \\
\text { Emily K. Burns, } \\
\text { Karen Albright and } \\
\text { Debra Flynn }\end{array}$ & & $\begin{array}{l}\text { Prospective } \\
\text { Cohort } \\
\mathrm{N}=40 \\
\text { Intervention: } \\
\text { Smoking cessation } \\
\text { treatment } \\
\text { navigation } \\
\text { (quit line, NRT, } \\
\text { medications) }\end{array}$ & $\begin{array}{l}\text { Quit attempt rate: } 70 \% \\
\text { Quit success rate: } 18 \%\end{array}$ & $\begin{array}{l}\text { Designed to assess } \\
\text { feasibility and not } \\
\text { intervention efficacy } \\
\text { Relied on self-reporting }\end{array}$ \\
\hline Year Published: 2015 & & & & \\
\hline $\begin{array}{l}\text { 6. Development of a } \\
\text { community-based } \\
\text { network to } \\
\text { promote smoking } \\
\text { cessation among } \\
\text { female smokers in } \\
\text { Hong Kong } \\
\text { Authors: } \\
\text { William H. C. Li, } \\
\text { Sophia S. C. Chan, } \\
\text { Zoe S. F. Wan, } \\
\text { M. P. Wang, K. Y. Ho and } \\
\text { T. H. LAM }\end{array}$ & $\begin{array}{l}\text { To describe the } \\
\text { development of a } \\
\text { community-based } \\
\text { network to promote } \\
\text { smoking cessation } \\
\text { among female smokers } \\
\text { in Hong Kong. }\end{array}$ & $\begin{array}{l}\text { Prospective cohort } \\
\text { Intervention: } \\
\text { 1. training of } \\
\text { cessation } \\
\text { volunteers } \\
\text { 2. provision of } \\
\text { gender specific } \\
\text { cessation } \\
\text { counseling }\end{array}$ & $\begin{array}{l}\text { Quit rate: } 28.4 \% \\
\text { Reduction in smoking } \\
\text { prevalence: } 50.3 \% \\
\text { The community-based } \\
\text { network program is } \\
\text { effective and feasible }\end{array}$ & $\begin{array}{l}\text { only } 14 \text { out of } \\
194 \text { women's } \\
\text { organizations joined } \\
\text { WATT and Only } \\
\text { eight of the 14-WATT } \\
\text { members participated } \\
\text { in our needs assessment } \\
\text { survey. }\end{array}$ \\
\hline
\end{tabular}

Year Published: 2017

APPENDIX B: BTI MODULE DESCRIPTION [21]

Table 5. Brief Tobacco Intervention Seminar and Workshop

\begin{tabular}{|c|c|c|c|c|}
\hline MODULE & $\begin{array}{l}\text { LEARNING OUTCOME } \\
\text { Participants will be able to: }\end{array}$ & COURSE DESCRIPTION & METHODOLOGY & CONTENTS \\
\hline $\begin{array}{l}\text { 1. Building the } \\
\text { momentum }\end{array}$ & $\begin{array}{l}\text { Describe the current } \\
\text { worldwide and national } \\
\text { burden of disease due to } \\
\text { tobacco use; } \\
\text { Describe the different } \\
\text { levels of Tobacco } \\
\text { Intervention; and } \\
\text { Describe the } \\
\text { different stages of Tobacco } \\
\text { Dependence. }\end{array}$ & $\begin{array}{l}\text { This module } \\
\text { provides background } \\
\text { information on the } \\
\text { national statistics for } \\
\text { tobacco use, tobacco } \\
\text { dependence, the most } \\
\text { common preventable } \\
\text { risk factor of illness and } \\
\text { death. }\end{array}$ & Lecture-discussion & $\begin{array}{l}\text { Tobacco Related } \\
\text { Statistics } \\
\text { Three-Link Chain of } \\
\text { Tobacco Dependence } \\
\text { Levels of Intensity in } \\
\text { Tobacco Interventions } \\
\text { Why Become a BTI } \\
\text { Provider? }\end{array}$ \\
\hline
\end{tabular}


Table 5. Brief Tobacco Intervention Seminar and Workshop (Continued)

\begin{tabular}{|c|c|c|c|c|}
\hline MODULE & $\begin{array}{l}\text { LEARNING OUTCOME } \\
\text { Participants will be able to: }\end{array}$ & COURSE DESCRIPTION & METHODOLOGY & CONTENTS \\
\hline 2. BTI Essentials & $\begin{array}{l}\text { Demonstrate the 5As (Ask, } \\
\text { Advice, Assess, Assist, } \\
\text { Arrange) as the effective } \\
\text { BTI methodology to assist } \\
\text { a tobacco user to quit } \\
\text { smoking and help them } \\
\text { stay quit; and Assess a } \\
\text { person's readiness to quit, } \\
\text { using the "Readiness to } \\
\text { Change" model. }\end{array}$ & $\begin{array}{l}\text { In this module, } \\
\text { participants will learn } \\
\text { how to determine a } \\
\text { person's readiness to } \\
\text { quit using tobacco and } \\
\text { be introduced to the Five } \\
\text { A's, a simple method } \\
\text { to help people quit } \\
\text { tobacco. }\end{array}$ & Lecture-discussion & $\begin{array}{l}\text { BTI Flowchart } \\
\text { The Readiness to } \\
\text { Change Model } \\
\text { The Five A's Learning } \\
\text { Activity: Readiness to } \\
\text { Change }\end{array}$ \\
\hline $\begin{array}{l}\text { 3. Not Ready to } \\
\text { Quit }\end{array}$ & $\begin{array}{l}\text { Participants will be able } \\
\text { to assess and identify } \\
\text { tobacco users who are not } \\
\text { yet ready to quit. }\end{array}$ & $\begin{array}{l}\text { In this module, } \\
\text { participants will be } \\
\text { guided on how to apply } \\
\text { the "Five A's" to help } \\
\text { tobacco users who } \\
\text { are not ready to quit. } \\
\text { Participants will watch } \\
\text { and discuss sample } \\
\text { interventions with the } \\
\text { facilitator, and will be } \\
\text { given time to practice } \\
\text { and demonstrate their } \\
\text { newly acquired skills }\end{array}$ & $\begin{array}{l}\text { Lecture-discussion; } \\
\text { role-playing }\end{array}$ & $\begin{array}{l}\text { Video role-plays: } \\
\text { "Not Ready to Quit" } \\
\text { and "Thinking about } \\
\text { Quitting" } \\
\text { Learning Activity: } \\
\text { Role-play and skills } \\
\text { development }\end{array}$ \\
\hline 4. Ready to Quit & $\begin{array}{l}\text { Identify tobacco users who } \\
\text { are ready to quit using } \\
\text { tobacco within the next } \\
\text { thirty days; } \\
\text { Describe the six basic } \\
\text { elements of a simple Quit } \\
\text { Plan and give a brief } \\
\text { explanation of each; } \\
\text { Effectively use the tobacco } \\
\text { intervention tools in the } \\
\text { Guidebook to deliver a } \\
\text { brief intervention; and } \\
\text { Apply the Brief } \\
\text { Intervention flowchart to } \\
\text { guide the intervention. }\end{array}$ & $\begin{array}{l}\text { In this module, } \\
\text { participants will continue } \\
\text { using the "Five A's" } \\
\text { to identify and assist } \\
\text { individuals who are } \\
\text { ready to quit using } \\
\text { tobacco within the next } \\
30 \text { days. Participant } \\
\text { will help the individual } \\
\text { who want to quit create } \\
\text { a simple Quit Plan by } \\
\text { setting a Quit Date and } \\
\text { identify basic strategies } \\
\text { to help in quitting, such } \\
\text { as finding supportive } \\
\text { people and learning } \\
\text { problem-solving skills. }\end{array}$ & $\begin{array}{l}\text { Lecture-discussion; } \\
\text { role-playing }\end{array}$ & $\begin{array}{l}\text { Video role-plays: } \\
\text { "Ready to Quit" } \\
\text { Learning Activity: } \\
\text { Role-play and skills } \\
\text { development }\end{array}$ \\
\hline $\begin{array}{l}\text { 5. Staying quit or } \\
\text { relapse }\end{array}$ & $\begin{array}{l}\text { Identify a person's tobacco } \\
\text { use status and readiness to } \\
\text { change during follow-up; } \\
\text { Identify at least two } \\
\text { reasons people relapse } \\
\text { and at least two relapse } \\
\text { prevention strategies; } \\
\text { Identify two recommended } \\
\text { for follow up contact with } \\
\text { tobacco users who have } \\
\text { developed a Quit Plan; } \\
\text { and } \\
\text { Give one example of a } \\
\text { follow-up reminder tool. }\end{array}$ & $\begin{array}{l}\text { In this module, } \\
\text { participants will gain the } \\
\text { skills needed to follow up } \\
\text { with tobacco users after } \\
\text { an initial intervention. } \\
\text { Skills on how to assist } \\
\text { tobacco users who have } \\
\text { stayed quit as well as } \\
\text { those who have relapsed } \\
\text { will be discussed in } \\
\text { this module. The skills } \\
\text { covered include the } \\
\text { timing of follow- ups to } \\
\text { get the best outcome, } \\
\text { how to create and } \\
\text { use simple re- minder } \\
\text { systems, and suggestions } \\
\text { for what to say during a } \\
\text { follow-up. }\end{array}$ & $\begin{array}{l}\text { Lecture-discussion; } \\
\text { role-playing }\end{array}$ & $\begin{array}{l}\text { Video role-plays: } \\
\text { "Ready to Quit" } \\
\text { Learning Activity: } \\
\text { Role-play and skills } \\
\text { development }\end{array}$ \\
\hline
\end{tabular}




\section{BRIEF TOBACCO INTERVENTION THE5A's}

1. ASK

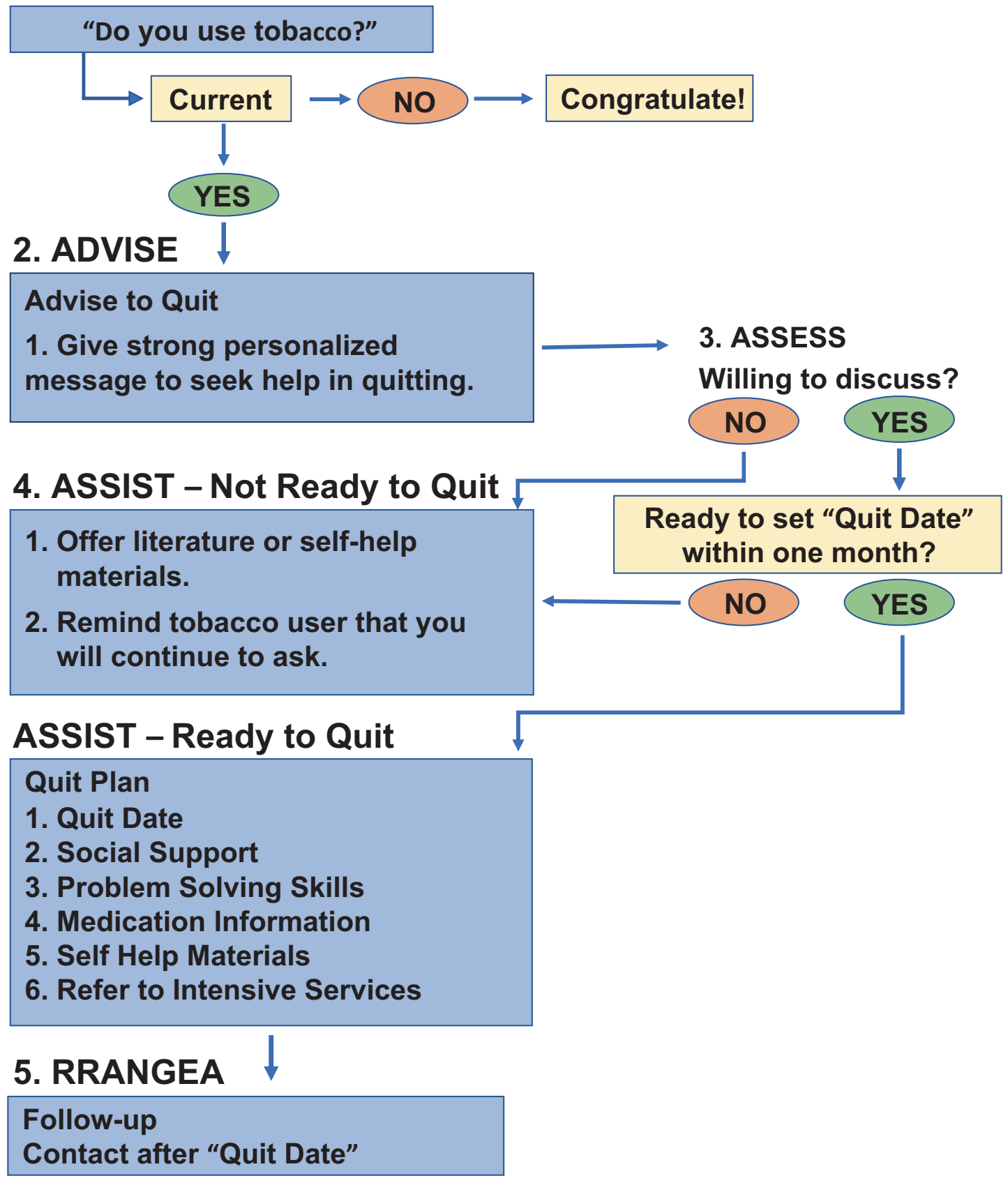

Figure 4 The 5A's in Brief Tobacco Intervention [21] 


\section{Readiness to Change Model}

Not Ready to Quit

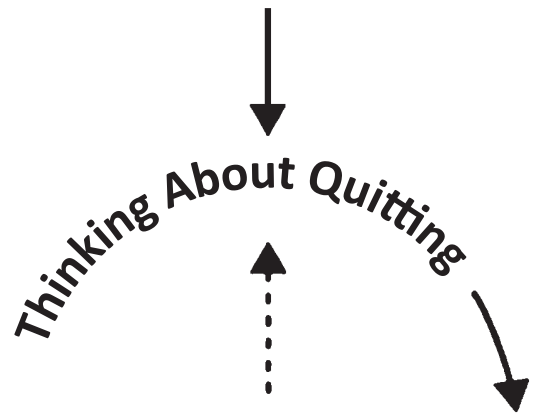

Termination

Staying Q

Relapse
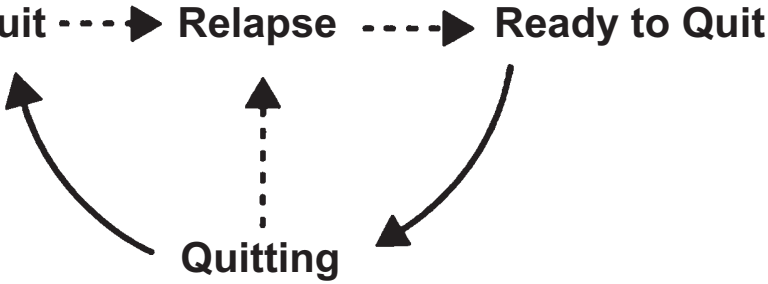

(Adapted from

Prochaska et al., 1997)

\begin{tabular}{|l|l|}
\hline \multicolumn{1}{|c|}{ Stage } & \multicolumn{1}{c|}{ Time Frame } \\
\hline Not ready to quit & No intentionto quit within 6 months \\
\hline $\begin{array}{l}\text { Thinking about } \\
\text { quitting }\end{array}$ & Intentionto quit in the next 6 months \\
\hline Ready to quit & Intentionto quit within 30 days \\
\hline Quitting & Stopped smoking for less than 6 months \\
\hline Staying quit & Tobaccofree for more than 6 months \\
\hline Relapse & $\begin{array}{l}\text { Using tobacco again after being } \\
\text { tobacco free }\end{array}$ \\
\hline
\end{tabular}

Figure 5: Readiness to change model [21] 